\title{
The Occult of Personality: Korea's Candlelight Protests and the Impeachment of Park Geun-hye
}

\section{JAMIE DOUCETTE}

ThE PHRASE "cult of personality" is used more often to describe North Korea's Kim 1 dynasty than the legacy of South Korean dictator Park Chung-hee, father of the recently impeached President Park Geun-hye. And yet Park's legacy has long been mythologized by conservative forces in both Korea and abroad as that of a virtuous and wise political leader. The praise of Park's virtues (especially his "economization of politics," as one prominent conservative economist puts it $)^{1}$ has many uses. During the Cold War, it was used to secure legitimacy for a president who had come to power through a military coup and whose vision of "administrative democracy" invested enormous power into the institution of the presidency itself. More recently, it has been deployed to help rewrite Korea's highly contentious development experience in a manner that praises both the state and oligarchic interests for past achievements. The myth of Park has been circulated through Korea's Official Development Assistance policies to help satisfy the demand for knowledge of Korea's development experience and to secure international prestige for the Korean development "model."” Meanwhile, intellectuals associated with Korea's New Right movement have praised Park’s much-vaunted legacy of economic planning and the establishment of a Korean middle class as prefiguring democracy, a narrative that is used to denigrate a history of democratic mobilization deemed dear to the liberal and progressive opposition and their supporters.

It seems that the unlucky fate of Park's daughter is to have inherited the aura that surrounds her father, for it is easier to mythologize the dead than it is the living. Nonetheless, Park Geun-hye was promoted as a desirable presidential candidate precisely because she was considered to be heir of her father's legacy. In an era of diminished economic growth and expanding inequality, she was seen as someone who might return the economy to the fabled high-growth era of Korea’s “developmental state." The collusion

Jamie Doucette (jamie.doucette@manchester.ac.uk) is Lecturer in Human Geography at the University of Manchester.

${ }^{1}$ Sung-Hee Jwa, Success Principles of Park Chung-hee: Economic Discrimination and Economization of Politics (Korea Development Institute School of Policy and Management, 2014), https://www.kdevelopedia.org/Resources/economy/success-principles-park-chung-hee--04201501270136474.do? fldIds=TP_ECO\%20TP_ECO_ES (accessed April 4, 2017). Jwa is currently chairman of the President Park Chung-hee Memorial Foundation and a professor at Yeungnam University's Park Chung-hee School of Policy and Saemaul.

${ }^{2}$ See, e.g., Juliette Schwak, "Branding South Korea in a Competitive World Order: Discourses and Dispositives in Neoliberal Governmentality," Asian Studies Review 40, no. 3 (2016): 427-44; Jamie Doucette and Anders Riel Müller, "Exporting the Saemaul Spirit: South Korea's Knowledge Sharing Program and the 'Rendering Technical' of Korean Development," Geoforum 75 (2016): 29-39. 
and corruption that animated her administration, however, quickly evaporated such wishes for meritocratic economic planning. It turns out that her personality was not that of the mythic modernizing will and rationality posited to be her father's but something seen by many as more perverse. The events that led to her impeachment thus provide an opportunity to analyze the effects of this cult in more detail, and, by extension, to reflect on how to critically understand the role of personality in the political imagination of Korean development and democratization. Such a topic is timely not only in the Korean context but also in the American one, and beyond, where the election of Donald Trump, the UK's vote to leave the European Union, and the presidential campaign of Marine Le Pen in France have led to a resurgence of discussion of the authoritarian personality and right-wing populism. ${ }^{3}$

\section{Persona vs. Personality}

To do so, it is worth briefly contrasting two ways of understanding the role of personality that have shaped research in the social sciences and the humanities: Antonio Gramsci's idea of the persona and Max Weber's concept of personality. Weber's ideal type approach to personality is better known and has played a formative role in the social sciences. It also resonated deeply with the national character studies popular within Asian studies during the interwar and immediate postwar era. For instance, Weber, much like Ruth Benedict, tended to see the personality as an active force in politics. Both found the sources of personality in interior motives and traits, such as passion, responsibility, charisma, shame, and vocation. They regarded personality as an ideal type that reflected the internalized values of a wider culture, a part that stood for a whole and that could be used to facilitate crosscultural comparison and prescribe social change. Moreover, as Sara Farris argues for Weber and C. Douglas Lummis for Benedict, these authors often saw the issue of personality in Asia as defined by a "lack" of qualities that they attributed to a putatively "Occidental" personality. ${ }^{4}$ Thus for critical scholarship, this approach to personality that seeks to find it in an individual's and by extension a culture's interior life posed some dangers. While it sought to historicize, if not relativize, forms of emotions, values, and activities, it also hazarded a reduction of social and structural differences to a series of individual or national attributes, or, even worse, perpetuated orientalist and racist stereotypes.

In contrast, Gramsci's idea of persona is one whose utility has been generally underexplored and that may provide us with a better understanding of the public drama behind Park's impeachment. In contrast to Weber's personality, Gramsci's saw the active historical persona as embodying "an interpenetration and concentration of social relations in a determinate, particular individual." Here it is not so much the individual's interior life

${ }^{3}$ For a critical discussion, see Peter E. Gordon, "The Authoritarian Personality Revisited: Reading Adorno in the Age of Trump," boundary 2 44, no. 2 (2017): 31-56.

${ }^{4}$ Sara R. Farris, Max Weber's Theory of Personality: Individuation, Politics and Orientalism in the Sociology of Religion (Leiden: Brill, 2013); C. Douglas Lummis, "Ruth Benedict's Obituary for Japanese Culture," Asia-Pacific Journal: Japan Focus 5, no. 7 (2007), http://apjjf.org/-C.-Douglas-Lummis/ 2474/article.html (accessed July 24, 2017).

${ }^{5}$ See Peter D. Thomas, The Gramscian Moment: Philosophy, Hegemony and Marxism (Leiden: Brill, 2009), 24:435. 
that is important as it is the geographically expansive social relations (which extend beyond the nation) that shape them and that, in the case of political leadership, they help mediate and/or command. In the Korean context, viewing Park as a persona might draw our attention away from simply focusing on the occult dimensions of her personality, and to the forces that have shaped her administration, that dominate Korean politics and economy, and that have used the cult of personality around her father to embolden elite power and safeguard their interests. Of course, this does not mean that we should neglect the juridical consequences of her actions as an individual, far from it. But we must also inquire into the systemic forces that shaped her regime and, ultimately, its downfall. For these forces will also shape the challenges of the regime that will replace Park.

I raise this argument because, initially, the mainstream coverage of the scandal and candlelight protests focused precisely on the occult elements of Park's personality, and these were represented to have provoked emotional protests. Furthermore, to some observers, these protests seemed to be irrationally motivated by national personality traits of shame, embarrassment, and damaged pride. ${ }^{6}$ Thus, the seemingly occult practices of Park's "shaman" Choi Soon-sil and her associates attracted attention, for indeed they provided tantalizing fodder for a political scandal, but this focus threatened distraction from some of the core systemic issues that helped lead to the protests and that seem sure to shape the policies of the newly elected Moon Jae-in administration. ${ }^{7}$ Some of the online commentary on the scandal even regressively connected Park's ineptitude to her gender-Park was Korea's female president. ${ }^{8}$ For many conservative voters, the esoteric practices and collusive relations at the heart of Park's regime tarnished her father's legacy and thus undermined his supposedly more legitimate "cult" of personality. ${ }^{9}$

In a sense, overcoming Park Geun-hye's strange, occult personality itself began to seem like a solution to the crisis, rather than overcoming the social relations that interpenetrated her position as a historical individual. In other words, an occulted view of Park Geun-hye's personality enables Park Geun-hye and Choi Soon-sil to be easily rendered scapegoats for the current political crisis and distracts from the cult of Park Chung-hee itself. However, it is that very "cult," in my opinion, that is more perverse inasmuch as it has been used to "occult" political power, that is, to make it seem mysterious, as something that flowed from Park's charismatic personality, and materialized through his will and intentionality.

${ }^{6}$ See, e.g., Euny Hong, "The President Who Got Impeached for Being Embarrassing," CNN, March 16, 2017, http://edition.cnn.com/2017/03/12/opinions/south-korea-america-differentdemocracies-opinion-hong/ (accessed April 4, 2017).

${ }^{7}$ Katherine H. S. Moon, "South Korea's Shamanic Panic: Park Geun-hye's Scandal in Context," Foreign Affairs, December 1, 2016, https://www.foreignaffairs.com/articles/south-korea/2016-1201/south-koreas-shamanic-panic (accessed April 10, 2017).

${ }^{8}$ See Choe Sang-Hun, "Gender Colors Outrage over Scandal Involving South Korea’s President," New York Times, November 21, 2016, https://www.nytimes.com/2016/11/22/world/asia/southkorea-park-geun-hye-women.html (accessed April 10, 2017). See also "Daŭm 'yŏsŏng taet’ongnyŏng' kkumdo kkuji mallanŭn idŭrege wŏnmunbogi” [To those who say not to dream for the next female president], Hankyoreh, January 3, 2017, http://www.hani.co.kr/arti/politics/polibar/ 777166.html (accessed April 4, 2017).

${ }^{9}$ See Steven Borowiec, “Dispatch from Gumi: Park Geun-Hye’s Sins Taint Father’s Legacy,” Korea Expose, December 22, 2016, https://koreaexpose.com/gumi-park-geun-hye-sins-taints-father/ (accessed April 11, 2017). 
The heroic view of Park Chung-hee has long been used to gloss over the unequal distribution of power that was institutionalized by Park's authoritarian regime, with its high-risk development strategies, repression of opposition, and regimentation of the population. It is a view that denigrates democratic principles and makes political power seem like magic, an extension of raw passionate personality, a view that avoids the questions of social power that shape politics, much less a vision of democratic politics as one involving careful deliberation, disagreement, and clear ideological principles. Thus, in what follows, rather than describing the internal flaws, so to speak, that have shaped the personality of Park the politician, I would like to map out a few of the more systemic social forces that have shaped her persona, forces that will likely provide ongoing challenges for any successor regime.

\section{The Ghost of Park Chung-hee}

While the selection of Park Geun-hye as a presidential candidate can be read as an attempt to extend the legacy of her father into present times, her actual electoral campaign began on a more conciliatory tone. Her economic campaign team itself was directed by an ensemble of moderate or "rational conservatives" who stressed economic reform and redistribution under the banner of "economic democracy." Of course, this did not prevent her from using her father's legacy and slogans such as "Let's live well" to promote herself to conservative voters. After her electoral victory, however, she quickly backed down on her reform pledges and distanced herself from the moderate conservatives who promoted them, one of whom, Kim Chong-in, would later come to lead the liberal opposition party. Instead, for advice Park relied on more hardline conservatives, many of who were anticommunist, public security prosecutors from her father's presidency and subsequent conservative regimes. Their style of politics reminded many of the dictatorship era of the 1970s and 1980s. Even before the end of the election campaign, the tenor of the conservative party seemed to have returned to red-baiting and witch hunts, with the leaking of alleged transcripts from the 2007 Inter-Korean Summit between Roh Moo-hyun and Kim Jong-il concerning Korea's North Limit Line and a social media campaign-later found to have been the work of the National Intelligence Service (NIS) and other state agencies—used to cast the liberal opposition as "Pro-North leftists."

Soon after her inauguration, Park's confrontation with the liberal-left opposition intensified, starting with the disbanding of the small, left-nationalist United Progressive Party and the deregistration of the Korean Teachers Union, and later followed by the surveillance and ill treatment of the families of the victims of the Sewól ferry disaster, and then the discovery of an extensive blacklist denying government funding to thousands of cultural figures who had voiced criticism, however tepid, of the Park government. In other words, Park's administration seemed to resurrect a style of politics associated

\footnotetext{
${ }^{10}$ Despite attempts to obstruct the investigation into electoral interference, NIS director Won Sei-hun would later be charged for spearheading this campaign in what was perhaps the first inkling that the Park administration would end in controversy.
} 
with the former dictatorial regimes of Park Chung-hee and Chun Doo Hwan. ${ }^{11}$ For many observers, this raised questions about the robustness of Korean democracy inasmuch as Park's uncommunicative disposition and preference for ruling by presidential veto and enforcement decree seemed to test the limits of procedural fairness. After she attacked moderate politicians in her own ruling party for seeking an agreement with the opposition party to overcome legislative roadblocks, it became clear that Park was seeking to consolidate power around the pro-Park faction of her party and her closest advisors. Moreover, it was later found that Park's power was insulated not only by these forces but also by a close confidante from her father's era, Choi Soon-sil. Park was later found to have leaked state secrets to Choi Soon-sil and to have been deeply involved in an active influencepeddling scheme with her.

\section{Forgotten LineAgES}

The figure of Choi raises some important, forgotten aspects of Korea's rapid development under authoritarian dictatorship that tend to be overlooked in studies of Korea's industrialization. Like the cult of Park, much of this literature makes a virtue of economic planning and adopts an idealized view of the autonomy and cohesion of the bureaucracy, and, by extension, the rational personality, or, rather, mentalité of elite bureaucrats. ${ }^{12}$ While this focus helps highlight specific industrial policies implemented by the state that were instrumental for rapid development, it often neglects the use of the coercive and patriarchal right hand of the state that was used to regiment the population for development, not to mention the anti-communist ideologies of the dictatorial regime and cult of personality built around Park Chung-hee that undergirded this effort. ${ }^{13}$

The lineage of Park Geun-hye's confidante Choi Soon-sil speaks to this understudied legacy. She is the daughter of Choi Tae-min, who founded an obscure, syncretic religious cult called Yŏngsegyo. Choi Tae-min mentored Park after her mother’s assassination in 1974, and she in turn helped lead his Mission for National Salvation, an organization that preached anti-communism with evangelical fervor throughout the 1970s as part of

\footnotetext{
${ }^{11}$ For an expanded account of these events, see Jamie Doucette and Se-Woong Koo, "Pursuing Post-Democratisation: The Resilience of Politics by Public Security in Contemporary South Korea," Journal of Contemporary Asia 46, no. 2 (2016): 198-221.

${ }^{12}$ This is a common thread of neo-Weberian scholarship in the developmental state in general that operates around an ideal-type understanding of elite bureaucracies as cohesive, "plan rational" organizations, to borrow a phrase from Chalmers Johnson. Meredith Woo-Cummings praises the "mentality" of the interventionist state in Korea as profoundly "results-oriented, privileging outcomes over established procedures and rules." See Meredith Woo-Cummings, Economic Crisis and Corporate Reform in East Asia (New York: Council on Foreign Relations, 2000), 44.

${ }^{13}$ For some discussion of the latter, see Seungsook Moon, Militarized Modernity and Gendered Citizenship in South Korea (Durham, N.C.: Duke University Press, 2005); Cho Hee-yeon, Dongwŏntuen kundaehwa [Mobilized modernization] (Seoul: Humanitas, 2010). For a recent view, see Kwang-Yeong Shin, "The Trajectory of Anti-Communism in South Korea," Asian Journal of German and European Studies 2, no. 3 (2017), doi:10.1186/s40856-017-0015-4. For a recent take on industrial policy and the power of the conglomerates, see Young-Jin Choi and Jim Glassman, "A Geopolitical Economy of Heavy Industrialization and Second Tier City Growth in South Korea: Evidence from the 'Four Core Plants Plan," Critical Sociology (2017), doi:10.1177/0896920517695868.
} 
an effort to attract Christian support for her father's regime. Even before the death of Park Chung-hee, Choi was alleged to be involved in influence peddling using Park's reputation. After the death of Park Sr., Choi was also involved in various fundraising schemes to memorialize his legacy. Park Geun-hye's close friendship with Choi's daughter extends from the mid-1970s and continued after the death of Choi Tae-min in 1994.

As the details of Choi Soon-sil and Park Geun-hye's influence peddling leaked out during the late summer and autumn of 2016, its vast extent and ostentatious manner surprised many. The gifts to Choi's daughter, Chung Yoo-ra, which included a literal gift horse from Samsung and a free ride at the nation's most prestigious women's university, spurred student protests that would eventually lead to Park's impeachment. ${ }^{14}$ Nonetheless, while Park and Choi's actions may have been vulgar and self-serving, they were not simply oriented toward the preservation of their own power, but also suited the interests and ambitions of other members of the elite. A number of Korea's large, family-led conglomerates, chaebŏl, including Samsung, Hyundai, SK, and LG, donated millions to the foundations run by Choi. The timing of the Samsung donation in particular came just before the National Pension Service approved a merger between Samsung affiliates that would guarantee the Samsung heir Lee Jae-young his management rights over the conglomerate. ${ }^{15}$ Samsung's "donation" should thus not be seen solely as an extension of Choi's peddling but should cast attention on the enduring problem of the chaeborl system, whose ruling families often exercise control not through direct ownership but instead through elaborate cross-shareholding arrangements. This structure makes it difficult for the heads of ruling families to lawfully pass on control of their conglomerates to the younger generations. Stock price manipulation, tunneling of contracts between firms, and other forms of financial fraud and collusion-often followed by pardons from the state-have been used to maintain their managerial control. The public has thus come to feel that there is one set of rules for the elite, those with "golden spoons" (see Hyejin Kim's article in this issue), and another for ordinary people.

In their rush to praise Korea's institutions of rapid economic growth, many scholars and popular commentators have often overlooked the dark of side of the developmental state, lauding the chaebŏl as a vital part of a "corrupt but competent" developmental coalition, and ignoring or sidelining questions of inequality, collusion, and poor labor standards. ${ }^{16}$ The dark side of this coalition, however, has become all the more clear in the current scandal, not only in the case of Samsung, but even more so in the case of the Sewŏl ferry accident: a tragedy that has in many ways touched on many hidden traumas of modern Korean history. The Sewŏl was operated by Ch’ŏnghaejin Marine Co. Ltd., a minor chaebŏl controlled by Yoo Byung-eun. Yoo was the founder of another salvation cult from the Park Chung-hee era, and had alleged ties to Choi Soonsil's ex-husband. Like other chaebŏl heads, Yoo controlled his company through elaborate

\footnotetext{
${ }^{14}$ Chung's coursework was allegedly completed by the teaching assistants of Jungerian writer Lee In-hwa, known for his praise of Park Chung-hee.

${ }^{15}$ See Choe Sang-Hun and Motoko Rich, "As Scandal Roils South Korea, Fingers Point to Mixing of Politics and Business," New York Times, January 2, 2017, https://www.nytimes.com/2017/01/02/ world/asia/south-korea-park-geun-hye-samsung.html (accessed April 12, 2017).

${ }^{16}$ At the same time, some of the most trenchant critics of crony capitalism have favored a deregulated market rather than prudential regulation and economic redistribution.
} 
cross-shareholding arrangements, which he used to enrich himself and his family. The staff of the overloaded ferry was predominantly made up of ill-trained employees on temporary contracts. Furthermore, regulatory failure due to self-regulation, parachute appointments, and lax enforcement in the shipping industry and naval rescue organizations further exacerbated the tragedy, as did the government's response to grieving families and slander of them by some conservatives as "pro-North" leftists. ${ }^{17}$ In other words, the tragedy exposed the fact that, indeed, the supposedly meritocratic bureaucracy working at the heart of the Korean state was little more than a myth. ${ }^{18}$

A quick look at some of the key actors involved in efforts to memorialize Park Chung-hee provides an interesting contrast to the received narrative of his regime as simply a benevolent, technocratic government. Instead, these efforts reveal a condensation, a concentrated solution, of some of the extensive social relations described above. ${ }^{19}$ After the death of Park Chung-hee, Choi Tae-min spearheaded various fundraising efforts to memorialize Park and his wife. These efforts and others eventually led to the establishment of the Park Chung Hee Memorial Foundation. Park's long-serving economic planner and secretary of state Kim Chung-yum was one of the first presidents of the commission that became the foundation, and former anti-communist prosecutor Kim Ki-Choon served as the foundation's first chairman. During the 1970s, Kim helped to draft Park Sr's dictatorial Yushin Constitution. He also served as Park Geunhye's chief of staff, was arrested for his role in the blacklist, and is thought to be responsible for the harsh treatment of the liberal-left during her administration. The current chairman at the time of this writing is the conservative economist Jwa Sung-hee, mentioned above, who is not shy in his praise of the former dictator. As the scandal broke in the fall of 2016, it was also found that Choi Soon-sil's Mir Foundation-the foundation that Choi and Park had "encouraged" many chaebol to fund—had drawn up plans to fund the renovation the Park Chung-hee Foundation buildings and other memorial projects. In other words, these efforts show a much more dense and living interaction of ideology, religion, political repression and collusion than the conventional story of Korean development as the effect of meritocratic economic planners often captures.

\section{Overcoming Park?}

The recent presidential election that followed Park's impeachment raises the important question of overcoming not just the specific personalities of Park Geun-hye and Choi

\footnotetext{
${ }^{17}$ See Nan Kim, "Candlelight and the Yellow Ribbon: Catalyzing Re-Democratization in South Korea," Asia-Pacific Journal: Japan Focus 15, no. 14(5), http://apjjf.org/-Nan-Kim/5057/article. pdf (accessed July 26, 2017).

${ }^{18}$ See Jong-sung You and Youn Min Park, "The Legacies of State Corporatism in Korea: Regulatory Capture in the Sewol Ferry Disaster," Journal of East Asian Studies 17, no. 1 (2017): 95-118. See also Jong-sung You, "Sewŏlho-wa Ch'oesunshil, yegodoen ch'amsa" [The Sewol ferry tragedy and Choi Soon-sil were predictable], Pressian, November 14, 2016, http://www.pressian.com/news/ article.html?no=144221 (accessed April 11, 2017).

${ }^{19}$ For an excellent discussion of the politics of memorializing Park, see Seungsook Moon, "The Cultural Politics of Remembering Park Chung Hee," Asia-Pacific Journal: Japan Focus 7, no. 19(5), http://apjjf.org/-Seungsook-Moon/3140/article.html (accessed June 5, 2017).
} 
Soon-sil, but, more so, some of the systemic and geographically expansive social relations that have shaped them as historic individuals. Here, there has been some cause for optimism but there is also a risk of focusing too much on personality and not enough on politics. There is a sense that the new administration of Moon Jae-in has offered reformers a second chance to carry on some of the ambitions of the liberal Roh Moo-hyun government after nearly ten years in opposition. Indeed, during the last few years of the Park administration, nostalgia arose for the personal style of Roh, who has come to be seen as an honest and sincere politician, as someone sensitive to the pains of the past and to the difficult struggles for democracy and recognition. ${ }^{20}$ Much of the initial commentary following Moon's electoral victory in May 2017 has focused on his personality as a rebirth of the Roh Moo-hyun spirit. Some of Moon's loyal followers have even set up fan clubs and websites pledging to defend Moon from criticism, which risk creating something of a liberal cult of personality around him. But, as the case of Park shows, this focus can distract us from broader systemic issues, including the political dilemmas encountered by the Roh administration itself.

The politics of the new administration should thus be evaluated on its ability to tackle some of the systemic issues that led to the scandal and to the protests that toppled Park Geun-hye. There are some good signals here in that the new government seems determined to reform the prosecution and to check the power of public security prosecutors, a move that seems to have wide public support following the electoral interference in the 2012 election and the blacklist of cultural figures, among other incidents. ${ }^{21}$ There are also good signs that the new Moon administration will make significant improvements on issues such as truth and reconciliation and inter-Korean engagement-longstanding demands that suffered under the Park administration ${ }^{22}$ — not to mention environmental and health and safety regulations. Likewise, the appointment of chaebŏl reformers from civil society organizations to prominent positions in the new administration is also a hopeful sign. However, there is also a danger here that the question of chaebŏl reform is treated too narrowly, as simply a question of shareholders' rights, and not as a question of social justice, in a manner that ignores the question of workers and other stakeholders. ${ }^{23}$ Likewise, despite the perception of Moon as a progressive reformer, he made homophobic statements during the presidential debates (though he later issued an

${ }^{20}$ For a good commentary on Roh nostalgia, see Hyung-A Kim, "President Roh Moo-Hyun's Last Interview and the Roh Moo-Hyun Phenomenon in South Korea," Journal of Contemporary Asia 47, no. 2 (2017): 273-98.

${ }^{21}$ See "Minjujuŭi gaehyŏk 1sun-wi shimindŭl kŏmch’al jŏnmunga bulp’yŏngdŭng” [First priorities for democratic reform: Citizens say prosecution, experts say inequality], Hankyoreh, February 13, 2017, http://www.hani.co.kr/arti/society/society_general/782359.html (accessed April 15, 2017).

${ }^{22}$ Nan Kim, Memory, Reconciliation, and Reunions in South Korea: Crossing the Divide (Lanham, Md.: Lexington Books, 2015).

${ }^{23}$ See Jamie Doucette, "Debating Economic Democracy in South Korea: The Costs of Commensurability," Critical Asian Studies 47, no. 3 (2015): 388-413, for a critical examination of how the question of chaebŏl has been discussed among some of the prominent economic reformers now appointed to spearhead chaebŏl reform. For a recent commentary, see Jang-jip Choi, "Ch’oejangjibŭi ‘kyŏngjeminjuhwa tamron' pip'an... ‘sanŏpchŏng shimingwŏnŭl yoguhaja”’ [Choi Jang-jip’s criticism of "economic democratization discourse": "Let's demand industrial citizenship"], Pressian, December 29, 2016, http://www.pressian.com/news/article.html?no=147270 (accessed April 15, 2017). 
apology, saying he was against discrimination). This episode exposed the fact that in order to appeal to conservative voters, even seasoned veterans of the democracy movement such as Moon and Seoul Mayor Park Won-soon (who angered LGBTQ groups by failing to enact an inclusive Seoul Charter of Human Rights) have not sufficiently challenged the forces of exclusion, the power of which they once made their reputations on by challenging. ${ }^{24}$

Moreover, if Moon is to provide a substantive alternative to the Park administration while also overcoming some of the difficulties of the Roh Moo-hyun government in which he served, it seems that the question of inequality must be front and center. There is a shared feeling among progressives that while the candlelight protests have finally managed shake off political actors associated with the old dictatorial regime-an accomplishment in itself and one that points to the maturity, so to speak, of Korean democracy - it would be a shame to leave unequal social relations intact. Thus, to better address inequality, critics have called for increased respect for labor's freedom of association, the tackling of gender inequality, and a reduction of precarious work. The difficult struggles of irregular workers over the past decade and a half have been testament to this issue in particular. ${ }^{25}$ Away from the workplace, the issue of affordable housing has also been fresh on many people's minds in the midst of a housing price bubble and ongoing processes of gentrification and displacement. ${ }^{26}$

But inequality is not simply something that is most felt between urban workers and their employers. There is also the persistent issue of urban-rural inequality. Many farmers find themselves threatened by debt, rural depopulation, and creeping agricultural liberalization, as well as corporate control of farm inputs and retail and distribution of farm products. While many joined in the protests against Park, others have continued to support the legacy of Park's father. They may remember the late 1970s as one of the few times that rural incomes seemed to catch up with urban incomes due to vigorous price support by a dictatorial government trying to secure support from farmers, as well as to consolidate the domestic food supply and to save foreign currency after the end of US food aid. ${ }^{27}$ While much of this is nostalgia inasmuch as Park's agricultural policies involved forced indebtedness and farm mechanization (which displaced labor and led to increased rural-urban migration), it is still a potent memory in an era of expanding inequality, one that is used to drum up support of regional conservative voters. What role farmers will play in the future administration, much less the mass of foreign migrant labor

\footnotetext{
${ }^{24}$ See Ju Hui Judy Han, “The Politics of Homophobia in South Korea," East Asia Forum Quarterly 8, no. 2 (2016): 6-7.

${ }^{25}$ See, e.g., Yoonkyung Lee, "Sky Protest: New Forms of Labour Resistance in Neo-Liberal Korea," Journal of Contemporary Asia 45, no. 3 (2015): 443-64.

${ }^{26}$ For some recent research on gentrification in Korea, see Hyun Bang Shin and Soo-Hyun Kim, "The Developmental State, Speculative Urbanisation and the Politics of Displacement in Gentrifying Seoul," Urban Studies 53, no. 3 (2016): 540-59; Laam Hae, "Traveling Policy: Place Marketing and the Neoliberal Turn of Urban Studies in South Korea," Critical Sociology (2017), doi: https://doi.org/10.1177/0896920517698539.

${ }^{27}$ Anders Riel Müller, "South Korea: Food Security, Development, and the Developmental State," in New Challenges to Food Security: From Climate Change to Fragile States, eds. Ian Christoplos and Adam Pain (New York: Routledge, 2014), 298-320.
} 
now working in fields and factories and virtually ignored in the campaign, is another question for the Moon administration.

Over the last few years, there have been growing calls to address many facets of inequality. In popular discourse, these are often discussed in terms of gap-eul relations, legal expressions that signify parties to a contract. "Gap" symbolizes the dominant party in a contract, while "eul" is the subordinate. These relations extend beyond that of employer and employee to include other power relations, including those between large and small corporations, regular and irregular workers, older and younger, professor and student, center and local, male and female, city and country, citizen and migrant, and more. Moon has inherited the call to address these relations, and in addition to the chaebŏl reforms discussed above he has promised to decentralize political power by promoting local government and pursuing balanced national development. The extent to which his government modifies a presidential system long criticized for the "imperial" power invested in it (a factor that enables the cult of personality around the president to begin with), much less addresses these many unequal relations, will crucially depend less on his personality and more on the ability of progressive political forces to propose alternatives to the current system and to institutionalize solutions to it. Moreover, his administration must be careful here that these do not rely on policies that simply embolden elite and corporate power, as happened during the Roh Moo-hyun and Kim Dae-jung administrations, whose neoliberal policies helped generate nostalgia for the Park dynasty that the conservatives used to regain political power.

To conclude, my point in this short article is that in our rush to find a new political personality, we should take care to not neglect the wider structural forces that shape Korean politics. It is a testament to the power of social movements in South Korea that the cult of both Park and his daughter, in particular, has been strongly and publicly contested. The recent candlelight protests — or candlelight revolution, to some-that led to the impeachment provide an important opportunity to overcome the legacy of this cult of personality. For some, Park's relationship with her spiritual advisor Choi Soon-sil has exposed a seemingly occult force at the center of power. But power always has an occult center in the sense that the mythical attribution of capacity to personality risks obscuring the expansive social relations that shape the actions of historically specific individuals. It is these relations that much of the popular discussion of Park and the scholarly obsession with her father's developmentalist rationality risk obscuring and that I have tried to explore here, if only in a cursory manner. The important question for the present moment then is not simply what kind of new personality will the new President Moon Jae-in bring to Korean politics, but, rather, what persona-what expansive set of social relations-will this historic person mediate and thus work to transform?

\section{Acknowledgments}

I wish to thank Se-woong Koo, Anders Riel Müller, and Albert Park for comments and suggestions on earlier drafts of this article. 